\title{
Dynamics of experimental governance : A meta-study of functions and uses of climate governance experiments
}

\section{Laakso, Senja}

2017-12-15

Laakso , S , Berg , A \& Annala , M 2017 , ' Dynamics of experimental governance : A meta-study of functions and uses of climate governance experiments ' , Journal of Cleaner Production , vol. 169 , pp. 8-16 . https://doi.org/10.1016/j.jclepro.2017.04.140

http://hdl.handle.net/10138/307600

https://doi.org/10.1016/j.jclepro.2017.04.140

cc_by_nc_nd

acceptedVersion

Downloaded from Helda, University of Helsinki institutional repository.

This is an electronic reprint of the original article.

This reprint may differ from the original in pagination and typographic detail.

Please cite the original version. 


\title{
Dynamics of experimental governance
}

\section{A meta-study of functions and uses of climate governance experiments}

Senja Laakso*; senja.laakso@helsinki.fi, Department of Environmental Sciences, P.O. Box 65, Viikinkaari 2 A, 00014 University of Helsinki, Finland

Annukka Berg, annukka.berg@ymparisto.fi, Finnish Environment Institute

Mikko Annala, mikko.annala@demoshelsinki.fi, Demos Helsinki

( ${ }^{*}$ Corresponding author)

\begin{abstract}
Societies around the world are faced with wicked problems such as climate change. In this context, experimental governance approaches have emerged as tools with potential utility in both top-down and bottom-up governance efforts. At the same time, experimental governance has gained momentum as a desirable policy goal in its own right. As the various experimental approaches differ in their origins and serve different purposes, there is a need to organize the field. If more experimental development processes are desired, what can be expected from certain kinds of experiments? How can the field be organised in a way that benefits those designing, conducting, and evaluating experimental governance processes? In attempting to answer these questions, we carried out a meta-study of 25 articles on experimental climate governance. On the basis of the results and the previous work on experiments, we have built a triangle model of experimental governance' that proposes both vertical and horizontal dynamics within and between different functions and uses of experiments.
\end{abstract}

\section{Key words}

Experiments; experimental governance; climate governance; meta-study; triangle model

\section{Highlights}

- The study focuses on potential functions and uses of experiments

- We conducted a meta-study of 25 papers about experimental climate governance

- Based on the results, we have built a 'triangle model of experimental governance'

- The model highlights vertical and horizontal dynamics of experimental governance 


\section{Introduction}

Sustainability experimentation has emerged as an approach that provides novel tools for tackling complex matters such as climate governance. One driver behind this development has been that traditional governance processes are ill equipped to address so-called wicked environmental and societal problems. Experimentation can provide new knowledge and discourses, and can increase momentum for broader change of technologies, policies, and institutions (Berkhout et al., 2010; Brown and Vergragt, 2008; Bulkeley and Castán Broto, 2013).

In the field of climate governance research, 'government by experiment' (Bulkeley and Castán Broto, 2013) has been met with interest ${ }^{1}$. The top-down appeal of governance experimentation lies in the fact that testing technologies, policies and participatory approaches on a small scale but under realworld conditions can yield valuable information and prompt new ways of learning (Bos and Brown, 2012; de Bruijne et al., 2010; Heilmann, 2008; Sabel and Zeitlin, 2012). At the same time, experimentation (especially within the sustainability transitions literature) has strong bottom-up appeal as a way to scale up successful grassroots initiatives, ideas, and actions (Ceschin, 2014; Schot and Geels, 2008; van den Bosch, 2010). The growing role of citizens in the development of society has been recognised, and new digital tools and social media are making it easier to foster bottom-up change (Annala et al., 2016; Berg, 2012).

Nevertheless, work in the field of experimental governance is still in many ways scattered. In general, many experimental approaches, such as transition experiments (e.g., van den Bosch 2010) and randomised trials (e.g., Torgerson, 2008), have been methodologically well developed in their own right. Yet scholars have pointed to a lack of frameworks covering how to approach experimental development work and governance as a whole (Bulkeley and Castán Broto, 2013; Kivimaa et al., 2015). In addition, it is important to note that progress towards transformations cannot be assessed solely on the basis of specific, measurable results such as reductions in greenhouse gas emissions (Laakso, 2017; Mickwitz et al., 2011). At the moment, few models have been offered that those designing, conducting, and evaluating sustainability experiments could utilise for choosing the most suitable experimentation framework and methodological tools (Berg et al., 2014).

To fill this gap, the article presents results from a meta-study of 25 articles on experimental climate governance. Through the meta-study, we seek to address the following research questions:

1. How can experiments be conceptualised on the basis of their potential functions and uses?

2. How should the dynamics and transformative potential of experimental governance be

\footnotetext{
2 Exemplified by international workshops such as the INOGOV workshop (see Section 3).
} 
understood?

With the meta-study, alongside a review of other key literature and our previous work on experimental governance in Finland (cf., Annala et al., 2016), we have attempted to create a framework that could be used for both analysing experiments on the basis of their key functions, and for structuring practical work on experiments. The results of the meta-study indicate that the key functions of experimentation can be divided into four categories: testing, creating profound influence, multiplying influence, and promoting systemic changes. In addition, there are both vertical and horizontal dynamics within and between the functions of experimentation. The outcomes of this study offer tools for organising the field of experimental governance and enhancing understanding of how the diverse experimental approaches being deployed might fit together in a strategy for societal transformation.

The following structure has been used for the article. Section 2 introduces the theoretical background of analysing experiments, and Section 3 presents the meta-study's materials and methods. Section 4 is a presentation of the results of our analysis, and Section 5 introduces the triangle model of experimental governance. Conclusions are drawn in the final section 6.

\section{Previous literature on typologies of experiments}

While few holistic models have structured experimental governance as a policy goal, studies have categorised governance experiments on the basis of, for instance, their normative orientation, theoretical foundation, analytical emphasis, and actors and forms of intervention (cf. Bulkeley and Castán Broto, 2013; Sengers et al., 2016a). In addition, studies have been based on the objectives, outputs, and outcomes of governance experiments (Kivimaa et al., 2015).

There are also typologies based on the key mechanisms of experiments (i.e., how they reach their goals, cf. Ghosh et al., 2016; Smith and Raven, 2012). Van den Bosch (2010; see also van den Bosch and Rotmans, 2008) identifies three mechanisms through which experiments contribute to transitions: 1) deepening highlights higher-order learning (both thinking and doing) and experimenting with a radically new structure, set of practices, and culture; 2) broadening explains the diffusion of novelties by repeating a transition experiment in a wider field or by broadening its function or application domain; and 3) scaling up addresses the social embedding of a transition experiment and the ways in which novelties can become mainstreamed. The categorisation bears resemblance to the typology of Schliwa et al. (2015), which was developed for understanding how living laboratories for sustainable urban transitions achieve their desired impacts. The authors 
identify three types of impact: direct, indirect, and diffuse. The first is measurable impact developed within the operational scope of a living lab project, while indirect impact results in follow-up activities that are beyond the scope of the project itself but inspired by it. Diffuse impact refers to the change in cultural and normative values within a society that takes place when the experimental project is evaluated.

Annala et al. (2016) have provided two models ${ }^{2}$ on the basis of experiences from government-led experimentation in Finland. First, experiments can be categorised on the basis of their size and scale. From this point of view, experiments can be divided into grassroots experiments at workplaces and organisations solving challenges in everyday living; experiments conducted in experimentation hubs (such as social media platforms or municipalities), supporting new courses of action and developing novel products and services for local and regional businesses; and strategic experiments of the government, which aim to solve wide societal challenges and give rise to evidence-based development of governance and legislation. The second categorisation also focuses on the size and scale of experiments, but is also loosely based on the mechanisms of van den Bosch (2010): a trial refers to an experiment which seeks to test whether a solution works or not. Deeper and scalable impacts illustrate the impact of an experiment within and outside the niche. Systemic change refers to national programmes promoting large-scale changes, such as the Finnish basic income experiment (Annala et al. 2016).

However, neither the categories outlined by Annala et al. (2016) nor the other existing typologies provide a holistic picture on the key functions (i.e., intended activity or purpose) of experiments or the dynamics of experimental (climate) governance as a whole. What can be expected from certain kinds of experiments and why, and how can these outcomes be achieved? How can the field of experimental governance be organised in a way that is of benefit to those designing, conducting, and evaluating the experiments? To answer to these questions, we now turn to the meta-study we conducted in our efforts to conceptualise the functions and uses of experimental governance and to identify conditions under which experimental governance can possess transformative potential.

\section{Materials and methods}

\footnotetext{
${ }^{2}$ Two of the authors were involved in the development of the models. Dr Annukka Berg is currently working at the Prime Minister's Office of Finland, promoting the government's Experimental Finland project. Mikko Annala, MSc, has been involved in experimental projects across the field of Finnish governance for example, by leading the development of conceptual and practical tools to support experimental governance in Finland (Annala et al., 2016). The two models are presented in Annala et al. (2016): the triangle model is a result of work conducted in the Finnish Prime Minister's Office and workshops organised by it. The development of the onion model included co-creation sessions with a group of specialists in the fields of e.g. financing and societal development (Annala et al. 2016).
} 
The meta-study to answer our research questions examined papers presented at the INOGOV workshop entitled 'Climate Change Policy and Governance: Initiation, Experimentation, Evaluation'. The workshop, which was held in Helsinki in March 2015, was developed to bring together the latest international and cross-disciplinary research focusing on climate-governance experiments, and hence the papers provide thematically suitable material for our study.

At the INOGOV workshop, 27 papers were presented, of which 26 (i.e., all but our own paper that formed a basis for the present article) were selected for the meta-study. As the papers presented were drafts, we requested permission to use them from the corresponding authors. The authors also had an opportunity to provide a more recent version of their paper, and published papers were used whenever available. One of the authors withheld permission, so 25 papers were ultimately analysed. These were mostly empirical in nature, but there were also some theoretical, meta-study, and review papers (Appendix A).

The categorisation schemes offering the most fruitful grounds for our purpose (i.e., organising the field of experimental governance in a holistic way) were those that were neither normative nor sector-, theory-, or methodology-specific. Hence, the most useful foundation was provided by those categorisations based on mechanisms of experiments, on how experiments work and reach their goals, and on the top-down and bottom-up dynamics (see, in particular, Annala et al., 2016; Schliwa et al., 2015; van den Bosch, 2010). The comparisons between these categories are presented in Table 1. To get a more comprehensive picture of the papers in the meta-study, we used a rather broad matrix of analysis that included categories that also addressed the theoretical and methodological roots, and the substantive foci and goals of the papers (Appendix B).

Table 1. Comparison of the typologies of Annala et al. (2016), Schliwa et al. (2015) and van den Bosch (2010).

\begin{tabular}{|l|l|l|l|}
\hline Author & Annala et al. (2016) & Schliwa et al. (2015) & van den Bosch (2010) \\
\hline Typology & size, scale, mechanism & desired impact & mechanism \\
\hline Categories & trials & direct impact & \\
\cline { 2 - 4 } & deeper impact & \multirow{2}{*}{ indirect impact } & deepening \\
\cline { 2 - 4 } & \multirow{2}{*}{ scalable impact } & & broadening \\
\cline { 3 - 4 } & & diffuse impact & scaling up \\
\cline { 2 - 4 } & systemic change & & \\
\hline
\end{tabular}

Following the methods of Kivimaa et al. (2015), we conducted a systematic search for attributes 
associated with the experiments (Appendix B), focusing both on how the authors approached the notion of experiments and on how the papers described any empirical data they dealt with. This was due to the fact that the workshop papers in our meta-study were theoretically and methodologically diverse, and our aim was to detect any possible functions and dynamics that were present in experiments within this diverse field. We categorised the experiments in each paper on the basis of attributes in the matrix, to identify the key activity, purpose and dynamics of an experiment, and then analysed how the experiments fit within the abovementioned typologies. Our findings are presented in the following sections.

\section{Results of the meta-study}

We have divided the presentation of results into two parts. Section 4.1 describes the central functions and uses of the experiments. The typology follows the four-part categorisation of Annala et al. (2016) and features the following main categories: 1) testing, 2) creating profound influence, 3) multiplying influence, and 4) promoting systemic change. Within this typology, categories are seen as functions of experiments, sharing the idea of impacts of Schliwa et al. (2015), but also of the mechanisms of change as they are understood by van den Bosch (2010). Furthermore, the categorisation borrows from the idea of analysing the potential uses of experiments (Berg and Hukkinen, 2011; Berg et al., 2014), with the key question being what can be expected from an experiment. Section 4.2 illustrates the dynamics within and between these four key functions.

\subsection{Key functions of experimental governance}

\section{Testing - ascertaining what works}

In the meta-study, testing was a function found to be frequently associated with experimenting - it is the 'hard core' of experiments. Experiments in this category are aimed at producing primarily (measurable) information and determining whether a solution or approach is working (Irvine and Kaplan, 2001; McFadgen, 2015; Schliwa et al., 2015). Testing appears straightforward: often, they can be done by anyone, do not require vast resources, and can be organised ad hoc. The uncertainty - and hence the probability of failure - in a testing set-up is high (Beermann and Tews, 2015; McFadgen, 2015).

The target of experiments of this nature is often in a community - a workplace, housing association, or neighbourhood, for instance (Edwards and Bulkeley, 2015; Trencher et al., 2016; Turnheim, 2015; 
Williams, 2016). The value lies in, for instance, delivering evidence, and raising public interest and awareness (Bos et al., 2015; McFadgen, 2015; Turnheim, 2015); pointing out obstacles to - and uncertainties surrounding - diffusion of new technologies (Fuchs and Hinderer, 2016; Raven et al., 2016; Saikku et al., 2016) or practices (den Uyl, 2015; Luederitz et al., 2016; Rocle and Salles, 2015); and finding ways to overcome these, as in mitigating the 'not in my backyard' problem (Young and Brans, 2015). In addition, scientific experiments can often be defined as tests, since they are systematically directed at producing new knowledge.

However, not all experiments focusing on information production are small in scale. Governance experiments, for instance, can be implemented as trials to test and demonstrate a new governance arrangement (Sabel and Zeitlin, 2012; Schroth, 2016; Twena, 2015). Tests are seldom the only avenue for carrying out sustainability experiments. They are, however, often useful starting points for example, in pilot projects, or forming part of more extensive projects that involve in-depth experimenting (Edwards and Bulkeley, 2015; Raven et al., 2016) or living laboratories (Schliwa et al., 2015). It is important to note also that local people are likely to evaluate and support experiments on different grounds than, for example, proponents of new products and services. Instead of promoting higher-order learning, they would prefer to produce concrete achievements through experiments (den Uyl, 2015; Heiskanen et al., 2015).

\section{Creating profound influence - learning and changing the practices}

In the second category, experiments are a) promoting conceptual and collective learning (van den Bosch, 2010) and b) fostering change in practices (Turnheim, 2015). These experiments are aimed at not merely producing information but also profoundly changing attitudes, norms, and framings within niches. Our study suggests that learning and gaining experiences are key factors in experimenting: learning was mentioned in almost all the papers as a central element of experimentation.

Bleicher et al. (2015) call for a distinction between learning as defined here and mere knowledge production for the sake of knowing: if experiments emphasise 'technological' learning outcomes (falling under 'testing' in our typology) instead of social, organisational, and institutional learning (or, in other words, focus on testing instead of facilitating higher-order learning or behavioural change), they remain constrained in their influence (Bos et al., 2015; Kivimaa et al., 2015). If change of practices is a key goal of an experiment, the latter fact needs to be taken into account in that experiment's design (Bos et al., 2015). 
Learning and changing practices were thus closely interlinked and frequently addressed simultaneously, with (higher-order) learning seen as leading to changing goals, discourses, preferences, and practices among societal actors (Bleicher et al., 2015; Kivimaa et al., 2015; McFadgen, 2015), and developing agency and identities (Turnheim, 2015; Twena, 2015). These experiments build capacities enabling people "to act sustainably in their everyday decision-making and practices" (Luederitz et al., 2016, 4). Learning and changes in practices, although specific to a particular context (Twena, 2015; Voß and Simons, 2016), were seen as a necessity if the experiments are to be broadened and scaled up. Shared problem frames, organisations, and documented ideas are "leftovers", outputs that "live on" after the experiments (Voß and Simons, 2016). As Luederitz et al. $(2016,4)$ describe, "typical indicators for built capacities are postexperiment activities and practices carried out by participants that have the potential to address the given sustainability problem, such as community gardening and food distribution systems, consumption of organic food products, launching of new sustainability-based businesses, expansion of networks, and incorporation of sustainability into decision-making in the public or private sector".

\section{Multiplying influence - experimenting beyond the niche}

Within the third category are experiments that work within, or are diffused between, multiple niches. These are often networks of experimental municipalities or cities (e.g., Beermann and Tews, 2015; Heiskanen et al., 2015; Trencher et al., 2016), creating frameworks for implementation across these networks. Experiments are thus designed to be conducted, diffused and repeated in different contexts and/or domains (van den Bosch, 2010; Wieczorek et al., 2015), leading to indirect impacts due to differences within the contexts and domains within which the experiments are implemented. In this category, 'multiplying' refers to both horizontal and vertical diffusion of experiments between niches, and to broadening and up-scaling the outcomes beyond the niche. Luederitz et al. (2016; see also van den Bosch and Rotmans, 2008) make a distinction between 'scaling out', which refers to repeating the experiment in the same context, and 'scaling up', which refers to integrating and applying the experiment at a higher system level.

The central means for multiplying influence are networks, as feedback from stakeholders and target groups is vital for understanding the potential for diffusion. Many of the papers highlighted the role of communities created around experiments (Bos et al., 2015; Korhonen-Kurki et al., 2015; Turnheim, 2015; Twena, 2015; Williams, 2016), as well as the role of new, decentralised actors, for instance, in the energy sector, as examples from Germany (Beermann and Tews, 2015; Young and Brans, 2015) and Finland (Saikku et al., 2016) attest. 
Multiplying influence requires more resources and capabilities to understand the viewpoints of the various actors than do the types of experiments discussed above. In order to realise an "energy transition from below", for instance, local initiatives need to "utilize their capacity as laboratories for decentralised energy solutions and prove that they are able to foster regional coordination of energy flows" (Beermann and Tews, 2015, 13). Workshops, forums, partnerships, and peer support related to experimenting help to establish common frames of reference for problems, sharing ideas and experiences related to how to address them, distributing the knowledge in new areas (McFadgen, 2015; Rocle and Salles, 2015; Schliwa et al., 2015; Turnheim, 2015; Twena, 2015; Wellstead et al., 2015), and testing people's reactions to various courses of action (Rocle and Salles, 2015). Substantial resources (Saikku et al., 2016; Young and Brans, 2015) and support structures (Schliwa et al., 2015; Williams, 2016) are often required for experiments to move or be generalised outside the niche (Schliwa et al., 2015; Turnheim, 2015; Young and Brans, 2015). Evaluation and "crosscase learning" are of importance too, since the impacts of an experiment beyond the niche may vary (Luederitz et al. 2016; Schliwa et al., 2015).

\section{Promoting systemic change - identifying and generating cracks}

In the final category are experiments aimed at promoting systemic changes - influencing how we think, speak, and act - in a more fundamental manner (Raven et al., 2016). Experiments of this sort challenge existing regimes and create alternative ways to conduct business as usual. The complexity of these experiments (Schroth, 2016; Voß and Simons, 2016; Zelli, 2015) was clear from the papers studied, and the broader the domain under scrutiny, the greater the degree of complexity.

Many of the experiments seen in this category were related to international top-down processes, such as emission-trading schemes (Schroth, 2016; Twena, 2015; Voß and Simons, 2016) and climate-change mitigation mechanisms (Korhonen-Kurki et al., 2015), challenging the existing regimes. The implementation of these experiments demands identification of cracks in the prevailing system, which the experiment can target. Experiments might even catalyse or generate cracks themselves, as scholars such as Heldeweg (2015) and Schroth (2016) have noted.

For systemic changes to occur, the outcomes of these experiments need to be linked to policymaking at multiple levels. Hence, experiments composed of multiple smaller processes, from local to national levels, are needed, to feed the change process, as are windows of opportunity for the system to adopt new courses of action (Korhonen-Kurki et al., 2015; Raven et al., 2016; Rocle and Salles, 2015). This renders the identification of an experiment and its boundaries ambiguous. An example from our meta-study is a process in which local, decentralised (niche) projects eventually changed 
the energy system in Germany (Beermann and Tews, 2015; Fuchs and Hinderer, 2016).

\subsection{Dynamics within and between functions}

Many of the papers examined in the meta-study were not limited only to targeting scaling up of experiments and their outcomes. Downscaling of national, or even international, policies to the local level by means of experimental settings was addressed, as was moving from one experimental setting to another (Rocle and Salles, 2015; Voß and Simons, 2015; Wellstead, 2015). When aiming at a holistic illustration of experimental governance, both vertical and horizontal dynamics should be acknowledged. The latter is often missing in the current approaches that focus mainly on top-down or bottom-up dynamics.

As for the vertical dynamics, many of the papers studied illustrate the movements between different functions and how they precede or complement one another. In many respects, the test and the knowledge gained from it form the core of experimenting. Hence, testing can be applied to both small and larger, more ambitious experiments, at multiple scales. For instance, as Schot and Geels (2008) note, niche development can be conceptualised as progressing simultaneously at the level of local projects and at the global niche level. However, most tests are small-scale, and it is typical for many experimental governance approaches to return to this category after feeding knowledge to 'higher' categories (e.g., Bleicher et al., 2015). There is thus often interaction between testing and the other categories.

The influence becomes more profound if the experiment is successful in bringing about higher-order (or social) learning and changes in practices beyond 'technological learning' (Brown et al., 2003; Sengers et al., 2016b). This requires a broad-based and iterative approach to learning, with inclusive learning goals, alongside monitoring and evaluation of progress over a series of steps and phases (den Uyl, 2015; Luederitz et al., 2016; Sengers et al., 2016b). These can also be new experiments, or what Williams (2016) calls "second wave experiments", that are used to gain deeper understanding about new management, financing and operational models on the basis of the first wave testing.

Multiplying the influence of the experiment beyond the niche level necessitates resources such as solid evidence as to the benefits with respect to the phenomenon examined in the experiment, networks, know-how, and expertise that facilitates processes of learning outside the niche (Fuchs and Hinderer, 2016; Rocle and Salles, 2015; Turnheim, 2015). As Saikku et al. (2016) and Williams (2016) note, gaps between experimentation and the introduction of support structures are especially likely to inhibit broadening and up-scaling. It is important to note that there needs to be a receptive 
environment for the experiments outside the niche for them to diffuse. Experiments cannot just be 'dropped in' to new locations or domains (Hodson and Marvin, 2007), but prior experience is needed for the new technologies or practices to take root outside the original context.

The most complex experiments can contribute to change in policies and cultures and can influence perceptions of sustainability problems, although these impacts are often beyond the direct scope of experimental projects (Schliwa et al., 2015). It is noteworthy that the papers studied mostly approached systemic change as being constituted of multiple smaller changes that are in constant interplay with the larger ones (Korhonen-Kurki et al., 2015; Voß and Simons, 2016). In contrast to 'zooming out' to a wider context, experiments can thus 'zoom in' (den Uyl, 2015; Turnheim, 2015) towards testing and gaining knowledge (Wellstead et al., 2015), or scale down towards the grassroots level. This, in turn, requires competence in adapting new features to local circumstances, as demonstrated by Trencher et al. (2016) in their study on programmes advancing energy efficiency and retro-fitting. However, the previous literature has generally neglected this scaling down of macroor meso-level initiatives to the micro-level, despite its significance particularly in relation to climate change policy (Wellstead et al., 2015).

Movement on the vertical dimension is from less to more complex functions and vice versa, but the horizontal dimension encompasses dynamics that are common to all experiments, whatever function they may fill or are supposed to perform.

Social processes such as networks and (cross-sectoral) co-operation have a major role in supporting horizontal diffusion and creating conditions for local and de-centralised experiments (Beermann and Tews, 2015; Turnheim, 2015). Our analysis demonstrated the ability of experimentation to create broader 'buzz', social capital, and community empowerment, beyond the experimental case in question (e.g., Edwards and Bulkeley, 2015; Schliwa et al., 2015; Turnheim, 2015). Media attention, for instance, can enhance the horizontal movement (Saikku et al., 2016). Knowledge for facilitating the change in the new context, dealing with other stakeholders, and navigating the complex institutional environments involved remains important (Fuchs and Hinderer, 2016; Ghosh et al., 2016). This also leaves space for the tactical or political use of experiments (Berg and Hukkinen, 2011; Edwards and Bulkeley, 2015; Young and Brans, 2015). Experiments can serve as political tools to install a new governance order or to garner political acceptability or authority (Bleicher et al., 2015; Schroth, 2016; Voß and Simons, 2016) or advocate particular interests and agendas (Raven et al., 2016; Zelli, 2015), reminding one that there are always subjective values behind the planning and evaluation of experiments (e.g., Raven et al., 2016; Twena, 2015). In addition, experiments often have a physical dimension and a spatial role that brings elements such as infrastructures to the heart of the experiment (e.g., Schliwa et al., 2015; Trencher et al., 2016). 
Geographical conditions shape experiments and might also limit their potential for transformation, highlighting the significance of the context and context-specific factors (Fuchs and Hinderer, 2016; Williams, 2016). This could also apply to (e.g.) historical, social and political contexts. Evaluation plays a key role in the diffusion of experiments (Schoenefeld and Jordan, 2015; Young and Brans, 2015) and the context-specific factors should be acknowledged in the evaluation processes. Also experiences of different stakeholders are important for understanding horizontal dynamics (e.g., den Uyl, 2015; Saikku et al., 2016; Turnheim, 2015).

\section{The triangle model as an illustration of experimental (climate) governance}

As the papers analysed have shown, the range of sustainability experiments is very broad, extending from home labs (Luederitz et al., 2016) to diffusion of innovative energy technologies and international climate governance (Twena, 2015; Zelli, 2015). Hands-on experimentation is about testing and applying new ideas, learning from them, and creating new practices and policies (e.g., Bos et al., 2015) in a constant dynamic process operating across contexts and scales (Bleicher et al., 2015; Korhonen-Kurki et al., 2015; Voß and Simons, 2016). In addition, in experimental cities and municipalities as living laboratories, a variety of experiments are being conducted simultaneously, interacting with, and influencing, each other. Being able to situate experiments in the field of experimental governance necessitates having a framework at our disposal that illustrates the many potential functions and uses of experiments, as well as the dynamics within and between them.

What is missing from the present typologies (cf. Section 2) is the notion about the key functions and uses of experiments: what are the main aims and purposes of experiments, and how are these achieved? Van den Bosch (2010), for instance, describes the process of change - how the experiment eventually shifts the regime - whereas Schliwa et al. (2015) illustrate how experiments have impacts that might be beyond the scope of the project itself. The results of our meta-study show that the four-part categorisation of Annala et al. (2016) provides a useful starting point for analysing the functions and uses of experimentation. In this typology, testing is added as a key category, as most of the papers in the meta-study recognised the importance of the direct, measurable impacts of experiments. The typology also recognises the role of large-scale experiments promoting systemic changes 'imposed from above'. Between these two categories are the experiments that are aimed at more profound influences within the niche, and multiplying influences between the niches. The typology therefore captures the bottom-up and top-down dynamics of experimental governance. 
As Section 4.1 showed, experiments and their outcomes can be valuable as such, instead of being just steps in the process of mainstreaming: they provide important information on local contexts and conditions, and create space for further experimentation, or they are scalable frameworks to be copied within different contexts or large (inter)national programmes to be implemented on a smaller scale. What Section 4.2 showed, is that all these experiments are valuable in experimental climate governance: complex experimental projects are broken down to practical measures at the niche level and small tests might gain influence due to social learning processes. The typology is thus useful for understanding different functions and uses of experimentation and can be applied to a variety of experiments of different theoretical or methodological roots. This is relevant especially for those working with climate governance experiments that can be highly diverse and thus not comparable on the basis of their other characteristics. In addition, the function perspective is helpful in evaluating the experiments: if systemic change was expected to follow from an experimental project, mere knowledge or even changed practices within a niche is a disappointment, while the production of high-quality data through experimenting is a good result when the goal was to carry out a welldesigned test.

The triangle model of experimental governance (see Fig. 1) graphically illustrates the individual functions of experiments and some of the key dynamics of experimental governance. By drawing on the previous work of Annala et al. (2016), as well as the other typologies that formed the basis of the meta-study, the model thus provides a synthesis of this previous work. The four categories are arranged in the triangle in a way that graphically depicts the growing influence of experiments by category. The triangle does not illustrate the growing size or scale of the experiments, but rather their complexity. For instance, testing can occur on multiple scales (from local to global), and multiplying influence can mean implementing the same experimental setting in two schools, or in two cities. Along the edges of the triangle are surrounding arrows representing the vertical (top-down and bottom-up) and horizontal dynamics within and between the functions. The model thus provides a synthesis of, and heuristics on the various aspects of experimental governance. 


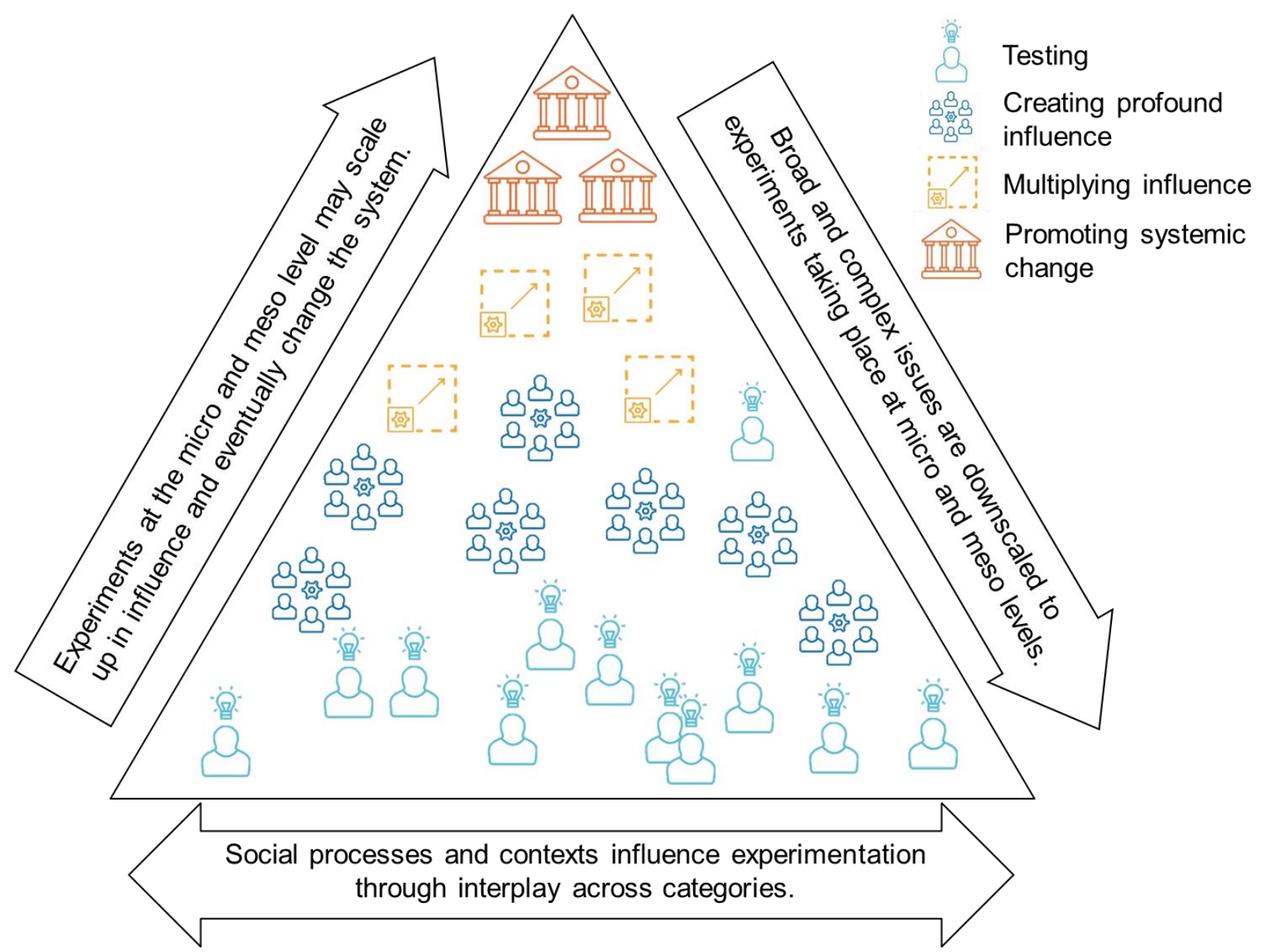

Figure 1. The triangle model of experimental governance.

The model is heuristic in the way that it provides a 'toolkit' for approaching experimentation. When designing, conducting, and evaluating experimental governance processes, it is important to understand why an experiment is done, how it works and what can be achieved. The model also improves decision making, as it opens up the dynamics of experimental governance: not only do experiments grow in size, or eventually scale up to become mainstream, but experiments are alternately zoomed in and out, and scaled down on the basis of experiences. Similarly, the horizontal dynamics illustrate the social, institutional, political, physical - or contextual - factors within and between the experimental settings. It is thus important to understand not only the aims and goals of an experiment, but also the ways the experiment is related to the other experiments and their outcomes. These dynamics are important especially at the local level, where a lot of different, overlapping experiments are conducted simultaneously (Laakso, forthcoming). Experiments should be used as part of broader activities and policies promoting and supporting change from above (Luederitz et al. 2016; van den Bosch \& Rotmans 2008). A broad range of bottom-up experiments, in turn, fulfil different roles and allow different types of innovation to be employed and tested (Berg et al., 2014; Laakso and Lettenmeier, 2016). 
The model complements the transition literature approaches, such as those of transition management (Loorbach 2010; van den Bosch 2010) and the multi-level perspective (Geels, 2010; 2011), which depict the growing influence of experiments and point out the need to exploit cracks in the system for regime shifts to occur (Geels, 2010). What the mechanisms of transition management are unable to capture is the versatility experiments and their horizontal dynamics. The triangle model gives equal weight to vertical and horizontal processes, acknowledging the strong top-down driver and cross-cutting themes behind many experimental settings. The model thus provides a useful tool towards a more differentiated view on complex experimentation processes and niche alignment. Broadening or scaling up should neither be the self-evident aim of experimentation, and not all innovations even wish to grow and diffuse (Farrelly \& Brown 2011; Kivimaa et al. 2015). Considering the multiple possible transition pathways (Geels \& Schot 2007; 2010), there is value also in experiments serving as a testing ground for exploring alternative technologies and services and how they work (or not) within a certain context.

The triangle model (Fig. 1) is intended to provide a holistic framework for understanding the potential functions and uses of many types of experiments. Further research is needed for empirical testing of the model, as is a better understanding of the role of various kinds of actors, networks, and drivers behind experiments (Heiskanen et al., 2010; Leminen et al., 2012; Wieczorek et al., 2015). How experiments and their functions are tied to certain contexts is another area that deserves further research. Greater effort could be invested in connecting the individual functions of experiments with relevant streams of literature. For example, creating profound, or multiplying, influence could be fruitfully analysed from the perspective of social practices (Hargreaves, 2011; Shove and Walker, 2007). These bodies of literature could aid in elaboration of the model and enhance experimental development work and governance as a whole.

\section{Conclusions}

To conceptualise experimental governance on the basis of the potential functions and uses of experiments, we formulated the four categories on the basis of the meta-study and previous typologies: testing, creating profound influence, multiplying influence, and promoting systemic change.

The scientific relevance of our study is in its contribution to the body of literature aimed at developing approaches for understanding experimental processes, especially in the field of climate governance. The most important contribution of this paper is the illustration of the vertical (top-down vs. bottomup) and horizontal dynamics within and between the functions of experimentation that the triangle model crystallises. These dynamics were present in one way or another in all the papers analysed. 
The model highlights that meeting the special criteria of each of the functions may fruitfully draw from several traditions and work methods. As the model thereby serves as an attempt to bridge the gaps between various scientific traditions informing the field of sustainability experiments, we hope that it can operate as a useful tool for climate governance scholars of various fields, seeking to understand the experimental turn in governance and governance cultures.

We also believe that our findings can be used outside academia to organise and clarify some key parts of the scattered field of experimental governance and sustainability experiments. The triangle model can help actors and evaluators working with experiments to discern the particular characteristics and opportunities afforded by a given experiment: it is important to understand what can be expected and gained, and what the requirements are for successful performing and achieving of individual functions. Visualisation of the functions and their dynamics might help actors at different levels to consider their roles and to develop coordination mechanisms spanning both horizontally and vertically.

\section{Acknowledgements}

Senja Laakso would like to acknowledge the financial support of the University of Helsinki doctoral programme in interdisciplinary environmental sciences (DENVI). Research by Annukka Berg has been conducted as part of the project Start-up Companies and Co-creation Communities As Ecosystems for Eco-innovations (SCINNO), financed by the Finnish Funding Agency for Innovation, Tekes.

\section{References}

Annala, M., Berg, A., Antikainen, R., Kaskinen, T., Alanko, L., Leppänen, J., 2016. Näkökulmia kokeilurahoitukseen - Ehdotus kokeilurahoitusalustan perustamisesta. Selvitys- ja tutkimustoiminnan julkaisusarja, no. 14. Helsinki.

Berg, A., 2012. The Multiple Faces of a Sustainability Strategy - Analysing Finland's Programme to Promote Sustainable Consumption and Production. Dissertation, University of Helsinki.

Berg, A., Hukkinen, J.I., 2011. Beyond effectiveness: The uses of Finland's national programme to promote sustainable consumption and production. Journal of Cleaner Production 19, 1788-1797. doi:10.1016/j.jclepro.2010.12.020

Berg, A., Hildén, M., Lahti, K., 2014. Kohti kokeilukulttuuria. Selvityksiä 77. Helsinki: Sitra. 
Berkhout, F., Verbong, G., Wieczorek, A.J., Raven, R., Lebel, L., Bai, X., 2010. Sustainability experiments in Asia: Innovations shaping alternative development pathways? Environmental Science and Policy 13, 261-271. doi:10.1016/j.envsci.2010.03.010

Bos, J.J., Brown, R.R., 2012. Governance experimentation and factors of success in socio-technical transitions in the urban water sector. Technological Forecasting and Social Change 79, 1340-1353. doi:10.1016/j.techfore.2012.04.006

Brown, H.S., Vergragt, P.J., 2008. Bounded socio-technical experiments as agents of systemic change: The case of a zero-energy residential building. Technological Forecasting and Social Change 75, 107-130. doi:10.1016/j.techfore.2006.05.014

Brown, H.S., Vergragt, P., Green, K., Berchicci, L., 2003. Learning for sustainability transition through bounded socio-technical experiments in personal mobility. Technology Analysis and Strategic Management 15, 291-315. doi:10.1080/09537320310001601496

Bulkeley, H., Castán Broto, V., 2013. Government by experiment? Global cities and the governing of climate change. Transactions of the Institute of British Geographers 38, 361-375. doi:10.1111/j.1475-5661.2012.00535.x

Ceschin, F., 2014. How the design of socio-technical experiments can enable radical changes for sustainability. International Journal of Design 8, 1-21.

de Bruijne, M., van de Riet, O., de Haan, A., Koppenjan, J., 2010. Dealing with dilemma's [sic]: How can experiments contribute to a more sustainable mobility system? European Journal of Transport and Infrastructure Research 10, 274-289.

Farrelly, M., Brown, R., 2011. Rethinking urban water management: Experimentation as a way forward? Global Environmental Change 21, 721-732. doi:10.1016/j.gloenvcha.2011.01.007

Geels, F.W., 2010. Ontologies, socio-technical transitions (to sustainability), and the multi-level perspective. Research Policy 39, 495-510. doi:10.1016/j.respol.2010.01.022

Geels, F.W., 2011. The multi-level perspective on sustainability transitions: Responses to seven criticisms. Environmental Innovation and Societal Transitions 1, 24-40. doi:10.1016/j.eist.2011.02.002

Ghosh, D., Sengers, F., Wieczorek, A.J., Ghosh, B., Roy, J., Raven, R., 2016. Urban mobility experiments in India and Thailand, in: Evans, J., Karvonen, A., Raven, R. (eds), The Experimental City. London / New York: Routledge, pp. 122-136.

Hargreaves, T., 2011. Practice-ing behaviour change: Applying social practice theory to pro-environmental behaviour change. Journal of Consumer Culture 11, 79-99. doi:10.1177/1469540510390500

Heilmann, S., 2008. Policy experimentation in China's economic rise. Studies in Comparative International Development 43, 1-26. doi:10.1007/s12116-007-9014-4 
Heiskanen, E., Jalas, M., Rinkinen, J., Tainio, P., 2015. The local community as a 'low-carbon lab': Promises and perils. Environmental Innovation and Societal Transitions 14, 149-164. doi:10.1016/j.eist.2014.08.001

Heiskanen, E., Johnson, M., Robinson, S., Vadovics, E., Saastamoinen, M., 2010. Low-carbon communities as a context for individual behavioural change. Energy Policy 38, 7586-7595. doi:10.1016/j.enpol.2009.07.002

Hodson, M. \& Marvin, S., 2007. Understanding the role of the national exemplar in constructing "strategic glurbanization." International Journal of Urban and Regional Research 31(2), 303-325.

Irvine, K.N., Kaplan, S., 2001. Coping with change: The small experiment as a strategic approach to environmental sustainability. Environmental Management 28, 713-725. doi:10.1007/s002670010256

Kivimaa, P., Hildén, M., Huitema, D., Jordan, A., Newig, J., 2015. Experiments in climate governance - lessons from a systematic review of case studies in transition research. SPRU Working Paper Series, ISSN 2057-6668.

Leminen, S., Westerlund, M., Nyström, A.-G., 2012. Living Labs as open-innovation networks. Technology Innovation Management Review 2(9), 6-11.

Laakso, S., 2017. Giving up cars - the impact of a mobility experiment on carbon emissions and everyday routines. Journal of Cleaner Production, DOI: 10.1016/j.jclepro.2017.03.035.

Laakso, S. \& Lettenmeier, M., 2016. Household-level transition methodology towards sustainable material footprints. Journal of Cleaner Production 132, pp.184-191.

Loorbach, D., 2010. Transition management for sustainable development: A prescriptive, complexity-based governance framework. Governance 23(1), 161-183.

Mickwitz, P., Hildén, M., Seppälä, J., Melanen, M., 2011. Sustainability through system transformation: Lessons from Finnish efforts. Journal of Cleaner Production 19, 1779-1787. doi:10.1016/j.jclepro.2011.07.011

Sabel, C.F., Zeitlin, J., 2012. Experimentalist Governance: The Oxford Handbook of Governance. doi:10.1093/oxfordhb/9780199560530.013.0012

Schliwa, G., Evans, J.P., McCormick, K., Voytenko, Y., 2015. Living Labs and sustainability transitions - assessing the impact of urban experimentation. Paper presented at the INOGOV workshop Climate Change Policy and Governance: Initiation, Experimentation, Evaluation, held in Helsinki on 12-13 March 2015.

Schot, J., Geels, F.W., 2008. Strategic niche management and sustainable innovation journeys: Theory, findings, research agenda, and policy. Technology Analysis and Strategic Management 20, 537-554. doi:10.1080/09537320802292651

Sengers, F., Wieczorek, A., Raven, R.P.J.M., 2016a. Experimenting for sustainability transitions: A systematic literature review. Technological Forecasting and Social Change. doi:10.1016/j.techfore.2016.08.031 
Sengers, F., Berkhout, F., Wieczorek, A.J., Raven, R., 2016b. Experiments in the city: Unpacking notions of experimentation for sustainability, in: Evans, J., Karvonen, A., Raven, R. (eds), The Experimental City. London / New York: Routledge, pp. 1-12.

Shove, E., Walker, G., 2007. Caution! Transition ahead: Policies, practice, and sustainable transition management. Environment and Planning A 39, 763-770. doi:10.1068/a39310

Smith, A., Raven, R., 2012. What is protective space? Reconsidering niches in transitions to sustainability. Research Policy 41, 1025-1036. doi:10.1016/j.respol.2011.12.012

van den Bosch, S., 2010. Transition Experiments: Exploring Societal Changes Towards Sustainability. Dissertation, Erasmus Universiteit Rotterdam.

van den Bosch, S., Rotmans, J., 2008. Deepening, broadening and scaling up: A framework for steering transition experiments. KCT essay no. 2. Knowledge Centre for Sustainable System Innovations and Transitions.

Torgerson, D., 2008. Designing Randomised Trials in Health, Education and Social Sciences: An Introduction. London: Palgrave Macmillan.

Wieczorek, A.J., Raven, R., Berkhout, F., 2015. Trsansnational linkages in sustainability experiments: A typology and the case of solar photovoltaic energy in India. Environmental Innovation and Societal Transitions 17, 149-165. doi:10.1016/j.eist.2015.01.001 
Appendix A: Papers presented at the INOGOV workshop held in Helsinki on 12-13 March 2015 (Climate Change Policy and Governance: Initiation, Experimentation, Evaluation)) and used in the meta-study

\begin{tabular}{|c|c|c|c|c|}
\hline Reference & $\begin{array}{l}\text { Type of } \\
\text { paper }\end{array}$ & $\begin{array}{l}\text { Related theory/ } \\
\text { literature }\end{array}$ & $\begin{array}{l}\text { Sector } \\
\text { and focus }\end{array}$ & $\begin{array}{l}\text { Type of } \\
\text { experiment/ } \\
\text { framework }\end{array}$ \\
\hline $\begin{array}{l}\text { Beermann, J., Tews, K., } 2015 . \\
\text { Preserving decentralised } \\
\text { laboratories for experimentation } \\
\text { under adverse framework } \\
\text { conditions - why local initiatives as } \\
\text { a driving force for Germany's } \\
\text { renewable energy expansion must } \\
\text { reinvent themselves. FFU Report } \\
\text { 03-2015. FFU Berlin. Available via } \\
\text { http://www.polsoz.fu- } \\
\text { berlin.de/polwiss/forschung/ } \\
\text { systeme/ffu/ffu-reports/15_ffu- } \\
\text { report_preserving/index.html. }\end{array}$ & empirical & $\begin{array}{l}\text { multilevel } \\
\text { governance } \\
\text { systems }\end{array}$ & energy & $\begin{array}{l}\text { decentralised } \\
\text { experimentation }\end{array}$ \\
\hline $\begin{array}{l}\text { Bleicher, A., Polzin, C., } \\
\text { Rauschmayer, F., et al., } 2015 . \\
\text { Advancing sustainability through } \\
\text { experiments - the concepts of } \\
\text { transition management and } \\
\text { reflexive governance revisited }{ }^{*} \text {. }\end{array}$ & $\begin{array}{l}\text { theoretical, } \\
\text { conceptual }\end{array}$ & $\begin{array}{l}\text { transition } \\
\text { management, } \\
\text { reflexive } \\
\text { governance }\end{array}$ & - & $\begin{array}{l}\text { sustainability } \\
\text { transition } \\
\text { experiments }\end{array}$ \\
\hline $\begin{array}{l}\text { Bos, J.J., Farrelly, M.A., Brown, } \\
\text { R.R., 2015. Designing experiments } \\
\text { to maximize learning potential*. }\end{array}$ & meta-study & $\begin{array}{l}\text { learning-by- } \\
\text { doing } \\
\text { approaches, } \\
\text { learning through } \\
\text { experimentation }\end{array}$ & water & $\begin{array}{l}\text { technical and } \\
\text { governance } \\
\text { experiment }\end{array}$ \\
\hline $\begin{array}{l}\text { den Uyl, R., Driessen, P., } 2015 . \\
\text { Evaluating governance for } \\
\text { sustainable development - Insights } \\
\text { from experiences in the Dutch fen } \\
\text { landscape. Journal of } \\
\text { Environmental Management } \\
\text { 163,186-203. }\end{array}$ & empirical & $\begin{array}{l}\text { adaptive } \\
\text { management, } \\
\text { transition } \\
\text { management }\end{array}$ & $\begin{array}{l}\text { water, } \\
\text { land use } \\
\text { (fens) }\end{array}$ & $\begin{array}{l}\text { experimentalist } \\
\text { governance }\end{array}$ \\
\hline $\begin{array}{l}\text { Edwards, G.A.S., Bulkeley, H., } \\
\text { 2015. Climate justice as urban } \\
\text { utopia*. }\end{array}$ & empirical & $\begin{array}{l}\text { Foucault's } \\
\text { concept of } \\
\text { 'heterotopia' }\end{array}$ & energy & $\begin{array}{l}\text { governance, } \\
\text { socio-technical, } \\
\text { and strategic } \\
\text { experiments }\end{array}$ \\
\hline $\begin{array}{l}\text { Fuchs, G., Hinderer, N., } 2016 . \\
\text { Towards a low carbon future: A } \\
\text { phenomenology of local electricity } \\
\text { experiments in Germany. Journal }\end{array}$ & empirical & $\begin{array}{l}\text { strategic action } \\
\text { fields }\end{array}$ & energy & $\begin{array}{l}\text { local } \\
\text { experimentation }\end{array}$ \\
\hline
\end{tabular}




\begin{tabular}{|c|c|c|c|c|}
\hline $\begin{array}{l}\text { of Cleaner Production 128, 97- } \\
104 .\end{array}$ & & & & \\
\hline $\begin{array}{l}\text { Heldeweg, M. A., } 2015 . \\
\text { Experimental legislation concerning } \\
\text { technological and governance } \\
\text { innovation - an analytical } \\
\text { approach. The Theory and Practice } \\
\text { of Legislation 3(2), 169-193. }\end{array}$ & theoretical & $\begin{array}{l}\text { legislation } \\
\text { theory }\end{array}$ & law & $\begin{array}{l}\text { analytical } \\
\text { framework for } \\
\text { the legal design } \\
\text { of experimental } \\
\text { legislation }\end{array}$ \\
\hline $\begin{array}{l}\text { Kivimaa, P., Hildén, M., Huitema, } \\
\text { D., et al. 2015. Experiments in } \\
\text { climate governance: Lessons from } \\
\text { a systematic review of case studies } \\
\text { in transition research. SPRU } \\
\text { Working Paper Series. Sussex. } \\
\text { Available via } \\
\text { http://sro.sussex.ac.uk/59245/. }\end{array}$ & $\begin{array}{l}\text { literature } \\
\text { review }\end{array}$ & $\begin{array}{l}\text { sustainable } \\
\text { transitions, } \\
\text { transition } \\
\text { management, } \\
\text { MLP }\end{array}$ & $\begin{array}{l}\text { many } \\
\text { sectors }\end{array}$ & $\begin{array}{l}\text { policy } \\
\text { experiments }\end{array}$ \\
\hline $\begin{array}{l}\text { Korhonen-Kurki, K., Brockhaus, M., } \\
\text { Muharrom, E., et al. } 2015 . \\
\text { Analyzing REDD+ as 'a pilot' of } \\
\text { transformative climate governance: } \\
\text { Insights from Indonesia*. }\end{array}$ & empirical & $\begin{array}{l}\text { transformative } \\
\text { governance }\end{array}$ & $\begin{array}{l}\text { land use, } \\
\text { forest } \\
\text { manage- } \\
\text { ment }\end{array}$ & $\begin{array}{l}\text { policy } \\
\text { experimentation }\end{array}$ \\
\hline $\begin{array}{l}\text { Luederitz, C., Schäpke, N., Wiek, } \\
\text { A., Lang, D.J., 2016. Learning } \\
\text { through evaluation - a tentative } \\
\text { evaluative scheme for sustainability } \\
\text { transition experiments. Journal of } \\
\text { Cleaner Production. } \\
\text { dx.doi.org/10.1016/j.jclepro.2016.0 } \\
9.005\end{array}$ & $\begin{array}{l}\text { literature } \\
\text { review, } \\
\text { conceptual }\end{array}$ & $\begin{array}{l}\text { transition } \\
\text { management } \\
\text { and governance }\end{array}$ & urban & $\begin{array}{l}\text { conceptual } \\
\text { framework for } \\
\text { the evaluative } \\
\text { scheme }\end{array}$ \\
\hline $\begin{array}{l}\text { McFadgen, B., 2015. Are we } \\
\text { learning-by-doing policy } \\
\text { experiments? The use of } \\
\text { experimentation in Dutch climate } \\
\text { adaptation and the effect of } \\
\text { experiment design on learning in a } \\
\text { policy network*. }\end{array}$ & empirical & $\begin{array}{l}\text { policy learning, } \\
\text { policy sciences, } \\
\text { science-policy } \\
\text { interfaces, } \\
\text { adaptive } \\
\text { management }\end{array}$ & $\begin{array}{l}\text { water, } \\
\text { land use }\end{array}$ & $\begin{array}{l}\text { policy } \\
\text { experiments }\end{array}$ \\
\hline $\begin{array}{l}\text { Raven, R.P.J.M., Ghosh, B., } \\
\text { Wieczorek, W., Stirling, A., } 2016 . \\
\text { Unpacking sustainabilities in socio- } \\
\text { technical transitions: Solar } \\
\text { photovoltaic and urban mobility } \\
\text { experiments in India and Thailand } \\
\text { (submitted manuscript). }\end{array}$ & empirical & $\begin{array}{l}\text { sustainable } \\
\text { transitions }\end{array}$ & $\begin{array}{l}\text { transport, } \\
\text { energy }\end{array}$ & $\begin{array}{l}\text { urban } \\
\text { experiments }\end{array}$ \\
\hline $\begin{array}{l}\text { Rocle, N., Salles, D., } 2017 . \\
\text { "Pioneers but not guinea pigs": } \\
\text { experimenting with climate change }\end{array}$ & empirical & $\begin{array}{l}\text { discursive } \\
\text { institutionalism }\end{array}$ & $\begin{array}{l}\text { land use } \\
\text { (coastal } \\
\text { areas) }\end{array}$ & $\begin{array}{l}\text { governance and } \\
\text { strategic } \\
\text { experimentation }\end{array}$ \\
\hline
\end{tabular}




\begin{tabular}{|c|c|c|c|c|}
\hline $\begin{array}{l}\text { adaptation in French coastal areas. } \\
\text { Policy Sciences. }\end{array}$ & & & & \\
\hline $\begin{array}{l}\text { Saikku, L., Tainio, P., Hildén, M., et } \\
\text { al., } 2017 \text {. Diffusion of solar } \\
\text { electricity in the network of private } \\
\text { actors as a strategic experiment to } \\
\text { mitigate climate change. Journal of } \\
\text { Cleaner Production } 142,2730 \text { - } \\
2740 .\end{array}$ & empirical & - & energy & $\begin{array}{l}\text { joint- } \\
\text { acquirement } \\
\text { experiments }\end{array}$ \\
\hline $\begin{array}{l}\text { Schliwa, G., Evans, J., McCormick, } \\
\text { K., Voytenko, Y., 2015. Living Labs } \\
\text { and sustainability transitions - } \\
\text { assessing the impact of urban } \\
\text { experimentation*. Available via } \\
\text { https://www.researchgate.net/publi } \\
\text { cation/280018177_Living_Labs_an } \\
\text { d_Sustainability_Transitions_-_Ass } \\
\text { essing_the_Impact_of_Urban_Exp } \\
\text { erimentation }\end{array}$ & $\begin{array}{l}\text { conceptual, } \\
\text { empirical }\end{array}$ & $\begin{array}{l}\text { transition } \\
\text { management }\end{array}$ & $\begin{array}{l}\text { transport, } \\
\text { built } \\
\text { environme } \\
\text { nt }\end{array}$ & $\begin{array}{l}\text { living labs, } \\
\text { urban } \\
\text { experimentation }\end{array}$ \\
\hline $\begin{array}{l}\text { Schoenefeld, J., Hildén, M., } \\
\text { Jordan, A., 2016. The challenges } \\
\text { of monitoring national climate } \\
\text { policy: learning lessons from the } \\
\text { EU. Climate Policy. }\end{array}$ & theoretical & $\begin{array}{l}\text { polycentric } \\
\text { governance and } \\
\text { evaluation }\end{array}$ & $\begin{array}{l}\text { climate } \\
\text { policy }\end{array}$ & $\begin{array}{l}\text { policy } \\
\text { experimentation }\end{array}$ \\
\hline $\begin{array}{l}\text { Schroth, F., 2016. Experimenting } \\
\text { with climate governance - the } \\
\text { politics and performativity of } \\
\text { governance experiments in the } \\
\text { construction of the 'Clean } \\
\text { Development Mechanism'*. }\end{array}$ & empirical & $\begin{array}{l}\text { science and } \\
\text { technology } \\
\text { studies }\end{array}$ & $\begin{array}{l}\text { climate } \\
\text { policy }\end{array}$ & $\begin{array}{l}\text { governance } \\
\text { experiments }\end{array}$ \\
\hline $\begin{array}{l}\text { Trencher, G., Castán Broto, V., } \\
\text { Takagi, T., et al., 2016. Innovative } \\
\text { policy practices to advance building } \\
\text { energy efficiency and retrofitting: } \\
\text { Approaches, impacts and } \\
\text { challenges in ten C40 cities. } \\
\text { Environmental Science \& Policy. } \\
\text { dx.doi.org/10.1016/j.envsci.2016.0 } \\
6.021\end{array}$ & empirical & $\begin{array}{l}\text { policy } \\
\text { innovations }\end{array}$ & energy & $\begin{array}{l}\text { programmes to } \\
\text { advance } \\
\text { energy-efficienc } \\
\text { y and retrofitting }\end{array}$ \\
\hline $\begin{array}{l}\text { Turnheim, B., 2015. Growing } \\
\text { spaces: Investigating interactions } \\
\text { between local sustainability } \\
\text { initiatives and socio-technical } \\
\text { niches in urban experiments with } \\
\text { urban agriculture and community } \\
\text { energy in Greater London*. }\end{array}$ & empirical & $\begin{array}{l}\text { sustainable } \\
\text { transitions, } \\
\text { MLP, SNM }\end{array}$ & $\begin{array}{l}\text { energy, } \\
\text { land use } \\
\text { (urban } \\
\text { gardening) }\end{array}$ & $\begin{array}{l}\text { multi-scale } \\
\text { sustainability } \\
\text { experiments }\end{array}$ \\
\hline
\end{tabular}




\begin{tabular}{|c|c|c|c|c|}
\hline $\begin{array}{l}\text { Twena, M., 2015. Experimentalist } \\
\text { governance in action: Lessons } \\
\text { from the European Climate Change } \\
\text { Programme*. }\end{array}$ & empirical & institutionalism & $\begin{array}{l}\text { climate } \\
\text { policy }\end{array}$ & $\begin{array}{l}\text { policy } \\
\text { experimentation }\end{array}$ \\
\hline $\begin{array}{l}\text { Voß, J.-P., Simons, A., } 2016 . \\
\text { Experimental politics. The } \\
\text { innovation of emissions trading } \\
\text { between lab and field. Policy } \\
\text { Sciences. }\end{array}$ & empirical & $\begin{array}{l}\text { science and } \\
\text { technology } \\
\text { studies }\end{array}$ & $\begin{array}{l}\text { climate } \\
\text { policy }\end{array}$ & $\begin{array}{l}\text { policy } \\
\text { experimentation }\end{array}$ \\
\hline $\begin{array}{l}\text { Wellstead, A., Howlett, M., Nair, S., } \\
\text { Rayner, J., 2016. "Push" dynamics } \\
\text { in policy experimentation: } \\
\text { Downscaling climate } \\
\text { change adaptation programs in } \\
\text { Canada. Climate Services } 4,52 \text { - } \\
60 .\end{array}$ & meta-study & - & $\begin{array}{l}\text { climate } \\
\text { policy }\end{array}$ & $\begin{array}{l}\text { policy } \\
\text { experimentation }\end{array}$ \\
\hline $\begin{array}{l}\text { Williams, J., 2016. Can low carbon } \\
\text { city experiments transform the } \\
\text { development regime? Futures } 77 \text {, } \\
80-96 .\end{array}$ & empirical & $\begin{array}{l}\text { sustainable } \\
\text { transitions }\end{array}$ & energy & $\begin{array}{l}\text { urban transition } \\
\text { experiments }\end{array}$ \\
\hline $\begin{array}{l}\text { Young, J., Brans, M., } 2015 . \text { The } \\
\text { evaluation of experimentalist } 100 \% \\
\text { renewable energy governance in } \\
\text { Germany - the case of [the] } \\
\text { Feldheim community*. }\end{array}$ & empirical & $\begin{array}{l}\text { sustainable } \\
\text { transitions }\end{array}$ & energy & $\begin{array}{l}\text { experimentalist } \\
\text { governance }\end{array}$ \\
\hline $\begin{array}{l}\text { Zelli, F., 2015. Institutionalism } \\
\text { revisited: Explaining institutional } \\
\text { complexity and experimentation in } \\
\text { global environmental governance* }\end{array}$ & theoretical & $\begin{array}{l}\text { institutional } \\
\text { complexity }\end{array}$ & energy & $\begin{array}{l}\text { governance } \\
\text { experiments }\end{array}$ \\
\hline
\end{tabular}


Appendix B: The categories in the meta-study

\begin{tabular}{|c|c|c|}
\hline Categories & & References \\
\hline \multirow[t]{3}{*}{$\begin{array}{l}\text { Theoretical and } \\
\text { methodological roots }\end{array}$} & Normative orientation & $\begin{array}{l}\text { Kivimaa et al., 2015; Sengers et al., } \\
2016 \mathrm{a}\end{array}$ \\
\hline & Theoretical foundation & $\begin{array}{l}\text { Bulkeley and Castán Broto, 2013; } \\
\text { Kivimaa et al., 2015; Sengers et al., } \\
2016 a\end{array}$ \\
\hline & Analytical emphasis & Sengers et al., $2016 a$ \\
\hline \multirow[t]{5}{*}{$\begin{array}{l}\text { Substantive focus, } \\
\text { outputs }\end{array}$} & Sector and focus & $\begin{array}{l}\text { Castán Broto and Bulkeley, 2013; } \\
\text { Kivimaa et al., } 2015\end{array}$ \\
\hline & $\begin{array}{l}\text { Location and scale, } \\
\text { local/ national }\end{array}$ & Kivimaa et al., 2015 \\
\hline & Actors & $\begin{array}{l}\text { Kivimaa et al., 2015; Sengers et al., } \\
2016 a\end{array}$ \\
\hline & Link to governance & Kivimaa et al., 2015 \\
\hline & Outputs & Kivimaa et al., 2015 \\
\hline \multirow[t]{6}{*}{$\begin{array}{l}\text { Impacts and } \\
\text { mechanisms }\end{array}$} & Testing/ direct impact & $\begin{array}{l}\text { Annala et al., 2016; Schliwa et al., } \\
2015\end{array}$ \\
\hline & Deepening & $\begin{array}{l}\text { Annala et al., 2016; van den Bosch, } \\
2010\end{array}$ \\
\hline & Broadening & van den Bosch, 2010 \\
\hline & Indirect impact & Schliwa et al., 2015 \\
\hline & $\begin{array}{l}\text { Scaling up/ diffuse } \\
\text { impact }\end{array}$ & $\begin{array}{l}\text { Annala et al., 2016; Kivimaa et al., } \\
\text { 2015; Schliwa et al., 2015; van den } \\
\text { Bosch, } 2010\end{array}$ \\
\hline & Systemic changes & Annala et al., 2016 \\
\hline
\end{tabular}

